\title{
UTLIZATION OF UNIFORMITY TRIALS TO ESTIMATE THE OPTIMUM PLOT SIZE AND SHAPE AND THE NUMBER OF REPLICATIONS IN MAIZE YIELD TRIALS
}

(Received:23.12.2013)

\author{
By \\ Sh. A. M. Shaboon, H. S. A. Fateh* and W. M. Fares* \\ Maize Research Section, Field Crops Research Institute,Agriculture Research Center, Giza,Egypt \\ *Central Laboratory for Design \&Statistical Analysis Research,Agriculture Research Center, Giza,Egypt
}

\begin{abstract}
In the present work, two uniformity trials were carried out during the first and the second summer seasons of 2011 and 2012 in the Experimental Field of Sids Agric. Res. Sta., ARC. The main objectives were to estimate the optimum plot size, shape and the optimum number of replicates for field research experiments on maize yield trials using the white maize single cross 10 as plant material. The cultivated area of each field trial was divided into 12 strips; each of which consisted of 48 rows with $3.0 \mathrm{~m}$ long and $70 \mathrm{~cm}$ apart. Two statistical methods including soil variability index and maximum curvature were used to estimate the optimum plot size and shape using the yield data of 576 basic units consisting of one row $\left(2.1 \mathrm{~m}^{2}\right)$. The results revealed that increasing plot size decreases the variance per basic unit and the coefficient of variability. The reduction was not in proportion to increase in plot size. The values of the soil variability index were 0.8984 and 0.7422 for the $1^{\text {st }}$ and the $2^{\text {nd }}$ seasons, respectively. The relationship between the coefficient of variability (C.V.) and plot size (x) was mathematically expressed by the equation: C.V. $=34.2 \mathrm{X}^{-0.6107}$ for the $1^{\text {st }}$ season and C.V. $=26.5 \mathrm{X}^{-0.4216}$ for the $2^{\text {nd }}$ one. Accordingly, using the soil variability index, the optimum plot size was 9 and 3 basic units $(1 / 222$ and $1 / 667$ fed.) for the $1^{\text {st }}$ and the $2^{\text {nd }}$ seasons, respectively, while it was 7 and 9 basic units $(1 / 286$ and $1 / 222$ fed.) when the maximum curvature method was applied. On the other hand, the long and narrow plots, for a specified plot size, had the lowest variances in the $1^{\text {st }}$ season while the short and wide plots were more efficient in the $2^{\text {nd }}$ season. The required number of replications for detecting a $15 \%$ difference among treatment means varied from 3 to 11 and from 4 to 10 in the $1^{\text {st }}$ and the $2^{\text {nd }}$ seasons, respectively. But, for detecting a $20 \%$ difference among treatment means, 2 to 6 replications in the $1^{\text {st }}$ season and 2 to 5 replications in the $2^{\text {nd }}$ one were found necessary.
\end{abstract}

Key words: maize, number of replicates, plot size and shape, uniformity trials.

\section{INTRODUCTION}

In field trials, the precision of significance tests are largely controlled by the size and shape of plots in addition to the area available for the particular trial, the nature of fertility and other soil variations. To cope with proper research practice, it has become necessary to standardize a suitable plot size and shape, and determine an optimum number of replicates for the major crops grown under different conditions. This will reduce the standard error of the experiments. The use of improper field-plot techniques may inflate the experimental error and lead to erroneous inferences. Hence, to improve the quality and credibility of research results, there is a need to proper on field plot techniques (Masood and Raza, 2012).

Federer (1955) pointed out that knowledge of soil heterogeneity of the experimental site is a pre- requisite for determining the optimum plot size and shape for different crops. To measure the soil heterogeneity, a uniformity trial is the first and the best method, for achieving this objective. The uniformity trial involves planting an experimental site with a single crop variety and applying all cultural and management practices as uniformly as possible. All sources of variability except those due to native soil difference are kept constant (Gomez and Gomez, 1984).

Galal and Abou El-Fittouh (1971) found that the optimum plot size for cotton trials was 18 to $29 \mathrm{~m}^{2}$. Plot shape was found to have no effect on the parameters investigated. Khalil et al. (1971) found that the optimum plot size for cotton yield trials ranged from $1 / 600$ to $1 / 300$ feddan, and from $1 / 300$ to $1 / 200$ feddan for Gemmiza and Sids locations, respectively. Kassem et al. (1972) estimated the optimum plot size and shape in 
wheat. They reported that the optimum plot size ranged from 4 to 6 and from 6 to 8 basic units in 1968 and 1969, respectively. The long and narrow plots significantly reduced the variability among (Joshi et al. 1973) plots compared with short wide or square plots. For soybean, trials indicated that the optimum plot size was about $11.25 \mathrm{~m} 2$. Khalil et al. (1973) found that the optimum plot size for paddy rice ranged from 1/ 1944 to $1 / 840$ feddan for paddy rice, and from 1/909 to 1/630 feddan for broad bean. Plot shape was found unimportant in both paddy and broad bean trials. El- Kalla and Gomaa (1977), working on kenaf grass stalk at Sakha and Gemmeiza in Egypt, found that the optimum plot size was $4.5 \mathrm{~m}^{2}$ at both locations by using Smith's procedure.

El-Rassas (1982) stated that the optimum plot size ranged from 4 to 8 basic units (1/300 to 1 $/ 150$ feddan) for wheat and maize, respectively. $\mathrm{He}$, also, found that long and narrow plots were more efficient in reducing variance per basic unit area.

El- Rayes et al. (1993) worked on wheat using each of maximum curvature method and Smith method. The results reflected that increasing the plot size decreased the variance per basic unit and the coefficient of variability. However, the reduction was not in proportion with the increase in plot size. The optimum plot size also ranged from 1/1000 to $1 / 750$ feddan, but, plot shape had no obvious effect in most cases in this study. ElTaweel (1999), showed that the number of replications in maize trials is expected to decrease by increasing the plot size. There was a gain in accuracy over the randomized complete block design. His results also showed that the average percent gain in precision was nearly the same when the plots were arranged either in a square or a rectangle. Ashmawy (2004) found that the optimum plot size for maize trials was one and two basic units (1/2000 and 1/1000 fed) for two seasons, respectively, using Smith method and 3 and 5 basic units (1/667 and 1/400 fed) using the maximum curvature method. But, plot shape had no clear effect in all cases. Increasing plot size generally decreased the number of replications required to detect differences of $15 \%$ and $20 \%$ among treatment means. Leilah and Al-Barrak (2005) conducted an uniformity trial on sorghum and concluded that both the variance per basic unit and the coefficient of variability tend to decrease with each increase in plot size. Mohamed (2005) found that the optimum plot size for maize trials ranged from 0.815 to 1.096 basic units $\left(8.557\right.$ to $\left.11.512 \mathrm{~m}^{2}\right)$ in two seasons using Smith's method, while the basic unit using the maximum curvature method was 2.58 to 3.7 (27.1 to 38.85 $\mathrm{m} 2)$. A plot size of $3.6 \mathrm{~m} 2(3.6 \mathrm{~m} \mathrm{x} 1.0 \mathrm{~m})$ was advisable for conducting field experiments in soybean (Kavitha, 2010). The optimum plot size based on the number of pods did not differ significantly from that determined by yield. Although the number of pods is economically best in determining the optimum plot size and shape, yield factor is considered to be the best for the purpose of identifying fertility contours and optimum plot size and shape.

In Egypt, few studies covered these research topics for various field crops especially maize. Therefore, the objectives of this work were to estimate the optimum plot size and shape to detect the optimum number of replicates for field experiments on maize yield trials.

\section{MATERIALS AND METHODS}

Two uniformity trials were carried out at the Agriculture Research Station of Sids, during the two successive growing seasons of 2011 and 2012 using the white maize single cross 10 . The study was designed to find out the optimum plot size, plot shape and the proper number of replications for maize experiments.

The cultivated area of each field trial was divided into 12 strips; each consisted of 48 rows of which $3.0 \mathrm{~m}$ long and $70 \mathrm{~cm}$ wide. Each row was considered as a basic unit i.e. $2.1 \mathrm{~m}^{2}$. Consequently, a total of 576 basic units were utilized for each trial in the two seasons. Twenty six seeds were planted per basic unit (row) and seedlings were manually thinned to 13 plants per unit resulting in a plant density of 26,000 plants per feddan. The cultural practices were carried out as commonly adopted in maize fields of Sids region. At harvest, the plants of every basic unit were harvested, shelled separately, and the grains were weighed to the nearest gram after adjusting moisture content in the grains to $15.5 \%$.

\section{Statistical Analysis}

Data collected from each uniformity trial were analyzed to estimate the soil heterogeneity index (b), the effect of plot size and shape on the variance per basic unit area $\left(\mathrm{v}_{\mathrm{x}}\right)$, comparable variance $(\mathrm{v})$, coefficient of variability (C.V.) and number of replications (r). Before running the statistical analysis, data were arranged in sequence. There were 45 plot combinations ranging from 1 to 144 basic units covering a abroad variety of plot sizes and shapes (Tables 1 and 2). Number of plots was calculated by dividing the total number of basic units (576 units) by the number of basic units for each plot size. 
Table (1): Variance and coefficients of variability for 45 combinations of plot sizes and shapes resulting from 576 basic units in 2011 season.

\begin{tabular}{|c|c|c|c|c|c|c|c|c|c|c|}
\hline \multirow{3}{*}{$\begin{array}{c}\text { Serial } \\
\text { No. }\end{array}$} & \multirow{2}{*}{\multicolumn{3}{|c|}{$\begin{array}{l}\text { Plot size \& shape } \\
\text { No. of basic units } \\
\end{array}$}} & \multirow{3}{*}{\begin{tabular}{|c} 
Plot \\
dimension (m) \\
width $x$ length
\end{tabular}} & \multicolumn{2}{|c|}{ Plot area } & \multirow{3}{*}{$\begin{array}{r}\text { No. of } \\
\text { plots }\end{array}$} & \multicolumn{2}{|c|}{ Variance } & \multirow{3}{*}{ CV \% } \\
\hline & & & & & \multirow{2}{*}{$\mathbf{m}^{2}$} & \multirow[b]{2}{*}{ Feddan } & & \multirow{2}{*}{\begin{tabular}{|c|} 
Per basic \\
unit \\
$(\mathrm{Vx})$ \\
\end{tabular}} & \multirow{2}{*}{$\begin{array}{c}\text { Among } \\
\text { plots } \\
\mathbf{V}(\mathbf{x}) \\
\end{array}$} & \\
\hline & Size & Rows & Strips & & & & & & & \\
\hline 1 & 1 & 1 & 1 & $0.7 \times 3.0$ & 2.1 & $1 / 2000$ & 576 & 0.118 & 0.118 & 22.927 \\
\hline 2 & 2 & 2 & 1 & $1.4 \times 3.0$ & 4.2 & $1 / 1000$ & 288 & 0.066 & 0.264 & 17.134 \\
\hline 3 & 2 & 1 & 2 & $0.7 \times 6.0$ & 4.2 & $1 / 1000$ & 288 & 0.076 & 0.305 & 18.429 \\
\hline 4 & 3 & 3 & 1 & $2.1 \times 3.0$ & 6.3 & $1 / 667$ & 192 & 0.033 & 0.298 & 12.135 \\
\hline 5 & 3 & 1 & 3 & $0.7 \times 9.0$ & 6.3 & $1 / 667$ & 192 & 0.06 & 0.543 & 16.401 \\
\hline 6 & 4 & 4 & 1 & $2.8 \times 3.0$ & 8.4 & $1 / 500$ & 144 & 0.025 & 0.401 & 10.571 \\
\hline 7 & 4 & 2 & 2 & $1.4 \times 6.0$ & 8.4 & $1 / 500$ & 144 & 0.044 & 0.707 & 14.032 \\
\hline 8 & 4 & 1 & 4 & $0.7 \times 1.2$ & 8.4 & $1 / 500$ & 144 & 0.051 & 0.819 & 15.103 \\
\hline 9 & 6 & 6 & 1 & $4.2 \times 3.0$ & 12.6 & $1 / 333$ & 96 & 0.013 & 0.483 & 7.734 \\
\hline 10 & 6 & 3 & 2 & $2.1 \times 6.0$ & 12.6 & $1 / 333$ & 96 & 0.018 & 0.661 & 9.043 \\
\hline 11 & 6 & 2 & 3 & $1.4 \times 9.0$ & 12.6 & $1 / 333$ & 96 & 0.037 & 1.312 & 12.743 \\
\hline 12 & 6 & 1 & 6 & $0.7 \times 18.0$ & 12.6 & $1 / 333$ & 96 & 0.041 & 1.468 & 13.476 \\
\hline 13 & 8 & 4 & 2 & $2.8 \times 6.0$ & 16.8 & $1 / 250$ & 72 & 0.016 & 0.998 & 8.336 \\
\hline 14 & 8 & 2 & 4 & $1.4 \times 12.0$ & 16.8 & $1 / 250$ & 72 & 0.030 & 1.888 & 11.463 \\
\hline 15 & 8 & 1 & 8 & $0.7 \times 24.0$ & 16.8 & $1 / 250$ & 72 & 0.037 & 2.356 & 12.807 \\
\hline 16 & 9 & 3 & 3 & $2.1 \times 9.0$ & 18.9 & $1 / 222$ & 64 & 0.012 & 0.963 & 7.276 \\
\hline 17 & 12 & 6 & 2 & $4.2 \times 6.0$ & 25.2 & $1 / 167$ & 48 & 0.007 & 0.984 & 5.517 \\
\hline 18 & 12 & 4 & 3 & $2.8 \times 9.0$ & 25.2 & $1 / 167$ & 48 & 0.013 & 1.795 & 7.453 \\
\hline 19 & 12 & 3 & 4 & $2.1 \times 12.0$ & 25.2 & $1 / 167$ & 48 & 0.008 & 1.116 & 5.876 \\
\hline 20 & 12 & 2 & 6 & $1.4 \times 18.0$ & 25.2 & $1 / 167$ & 48 & 0.027 & 3.888 & 10.967 \\
\hline 21 & 12 & 1 & 12 & $0.7 \times 36.0$ & 25.2 & $1 / 167$ & 48 & 0.033 & 4.646 & 11.989 \\
\hline 22 & 16 & 4 & 4 & $2.8 \times 12.0$ & 33.6 & $1 / 125$ & 36 & 0.010 & 2.612 & 6.742 \\
\hline 23 & 16 & 2 & 8 & $1.4 \times 24.0$ & 33.6 & $1 / 125$ & 36 & 0.025 & 6.439 & 10.586 \\
\hline 24 & 16 & 1 & 16 & $0.7 \times 48.0$ & 33.6 & $1 / 125$ & 36 & 0.030 & 7.564 & 11.473 \\
\hline 25 & 18 & 3 & 6 & $2.1 \times 18.0$ & 37.8 & $1 / 111$ & 32 & 0.006 & 1.954 & 5.183 \\
\hline 26 & 18 & 6 & 3 & $4.2 \times 9.0$ & 33.8 & $1 / 111$ & 32 & 0.005 & 1.501 & 4.543 \\
\hline 27 & 24 & 6 & 4 & $4.2 \times 12.0$ & 50.4 & $1 / 83$ & 24 & 0.003 & 1.673 & 3.597 \\
\hline 28 & 24 & 4 & 6 & $2.8 \times 18.0$ & 50.4 & $1 / 83$ & 24 & 0.008 & 4.807 & 6.097 \\
\hline 29 & 24 & 3 & 8 & $2.1 \times 24.0$ & 50.4 & $1 / 83$ & 24 & 0.005 & 2.577 & 4.464 \\
\hline 30 & 24 & 2 & 12 & $1.4 \times 36.0$ & 50.4 & $1 / 83$ & 24 & 0.023 & 13.174 & 10.094 \\
\hline 31 & 24 & 1 & 24 & $0.7 \times 72.0$ & 50.4 & $1 / 83$ & 24 & 0.028 & 16.079 & 11.152 \\
\hline 32 & 32 & 4 & 8 & $2.8 \times 24.0$ & 67.2 & $1 / 63$ & 18 & 0.008 & 7.797 & 5.824 \\
\hline 33 & 32 & 2 & 16 & $1.4 \times 48.0$ & 67.2 & $1 / 63$ & 18 & 0.021 & 21.867 & 9.754 \\
\hline 34 & 36 & 6 & 6 & $4.2 \times 18.0$ & 75.6 & $1 / 55$ & 16 & 0.002 & 1.975 & 2.606 \\
\hline 35 & 36 & 3 & 12 & $2.1 \times 36.0$ & 75.6 & $1 / 55$ & 16 & 0.003 & 3.348 & 3.393 \\
\hline 36 & 48 & 6 & 8 & $4.2 \times 24.0$ & 100.8 & $1 / 42$ & 12 & 0.001 & 2.218 & 2.071 \\
\hline 37 & 48 & 4 & 12 & $2.8 \times 36.0$ & 100.8 & $1 / 42$ & 12 & 0.007 & 15.932 & 5.55 \\
\hline 38 & 48 & 3 & 16 & $2.1 \times 48.0$ & 100.8 & $1 / 42$ & 12 & 0.001 & 2.995 & 2.406 \\
\hline 39 & 48 & 2 & 24 & $1.4 \times 72.0$ & 100.8 & $1 / 42$ & 12 & 0.022 & 50.386 & 9.870 \\
\hline 40 & 64 & 4 & 16 & $2.8 \times 48.0$ & 134.4 & $1 / 31$ & 9 & 0.006 & 25.717 & 5.289 \\
\hline 41 & 72 & 6 & 12 & $4.2 \times 36.0$ & 151.2 & $1 / 28$ & 8 & 0.0003 & 1.736 & 1.221 \\
\hline 42 & 72 & 3 & 24 & $2.1 \times 72.0$ & 151.2 & $1 / 28$ & 8 & 0.002 & 9.914 & 2.919 \\
\hline 43 & 96 & 6 & 16 & $4.2 \times 48.0$ & 201.6 & $1 / 21$ & 6 & 0.00002 & 0.164 & 0.282 \\
\hline 44 & 96 & 4 & 24 & $2.8 \times 72.0$ & 201.6 & $1 / 21$ & 6 & 0.006 & 59.222 & 5.351 \\
\hline 45 & 144 & 6 & 24 & $4.2 \times 72.0$ & 302.4 & $1 / 14$ & 4 & 0.00002 & 0.516 & 0.333 \\
\hline
\end{tabular}


Sh. A. M. Shaboon et al.,.............................................................................

Table (2): Variance and coefficients of variability for 45 combinations of plot sizes and shapes resulting from 576 basic units in 2012 season.

\begin{tabular}{|c|c|c|c|c|c|c|c|c|c|c|}
\hline \multirow{3}{*}{$\begin{array}{l}\text { Serial } \\
\text { No. }\end{array}$} & \multirow{2}{*}{\multicolumn{3}{|c|}{$\begin{array}{l}\text { Plot size \& shape } \\
\text { No. of basic units }\end{array}$}} & \multirow{3}{*}{$\begin{array}{c}\text { Plot } \\
\text { dimension (m) } \\
\text { width } x \text { length }\end{array}$} & \multicolumn{2}{|c|}{ Plot area } & \multirow{3}{*}{$\begin{array}{r}\text { No. of } \\
\text { plots }\end{array}$} & \multicolumn{2}{|c|}{ Variance } & \multirow{3}{*}{$\mathrm{CV} \%$} \\
\hline & & & & & \multirow{2}{*}{$\mathbf{m}^{2}$} & \multirow[b]{2}{*}{ Feddan } & & \multirow{2}{*}{$\begin{array}{c}\text { per } \\
\text { basic } \\
\text { unit } \\
(\mathbf{V x})\end{array}$} & \multirow{2}{*}{$\begin{array}{l}\text { among } \\
\text { plots } \\
\mathbf{V}(\mathbf{x})\end{array}$} & \\
\hline & Size & Rows & Strips & & & & & & & \\
\hline 1 & 1 & 1 & 1 & $0.7 \times 3.0$ & 2.1 & $1 / 2000$ & 576 & 0.193 & 0.193 & 23.70 \\
\hline 2 & 2 & 2 & 1 & $1.4 \times 3.0$ & 4.2 & $1 / 1000$ & 288 & 0.120 & 0.481 & 18.70 \\
\hline 3 & 2 & 1 & 2 & $0.7 \times 6.0$ & 4.2 & $1 / 1000$ & 288 & 0.112 & 0.447 & 18.03 \\
\hline 4 & 3 & 3 & 1 & $2.1 \times 3.0$ & 6.3 & $1 / 667$ & 192 & 0.095 & 0.857 & 16.64 \\
\hline 5 & 3 & 1 & 3 & $0.7 \times 9.0$ & 6.3 & $1 / 667$ & 192 & 0.087 & 0.784 & 15.92 \\
\hline 6 & 4 & 4 & 1 & $2.8 \times 3.0$ & 8.4 & $1 / 500$ & 144 & 0.084 & 1.341 & 15.62 \\
\hline 7 & 4 & 2 & 2 & $1.4 \times 6.0$ & 8.4 & $1 / 500$ & 144 & 0.076 & 1.213 & 14.85 \\
\hline 8 & 4 & 1 & 4 & $0.7 \times 1.2$ & 8.4 & $1 / 500$ & 144 & 0.067 & 1.076 & 13.99 \\
\hline 9 & 6 & 6 & 1 & $4.2 \times 3.0$ & 12.6 & $1 / 333$ & 96 & 0.072 & 2.576 & 14.43 \\
\hline 10 & 6 & 3 & 2 & $2.1 \times 6.0$ & 12.6 & $1 / 333$ & 96 & 0.065 & 2.330 & 13.72 \\
\hline 11 & 6 & 2 & 3 & $1.4 \times 9.0$ & 12.6 & $1 / 333$ & 96 & 0.065 & 2.327 & 13.71 \\
\hline 12 & 6 & 1 & 6 & $0.7 \times 18.0$ & 12.6 & $1 / 333$ & 96 & 0.047 & 1.688 & 11.68 \\
\hline 13 & 8 & 4 & 2 & $2.8 \times 6.0$ & 16.8 & $1 / 250$ & 72 & 0.060 & 3.828 & 13.19 \\
\hline 14 & 8 & 2 & 4 & $1.4 \times 12.0$ & 16.8 & $1 / 250$ & 72 & 0.048 & 3.061 & 11.80 \\
\hline 15 & 8 & 1 & 8 & $0.7 \times 24.0$ & 16.8 & $1 / 250$ & 72 & 0.029 & 1.835 & 9.13 \\
\hline 16 & 9 & 3 & 3 & $2.1 \times 9.0$ & 18.9 & $1 / 222$ & 64 & 0.057 & 4.637 & 12.91 \\
\hline 17 & 12 & 6 & 2 & $4.2 \times 6.0$ & 25.2 & $1 / 167$ & 48 & 0.054 & 7.773 & 12.53 \\
\hline 18 & 12 & 4 & 3 & $2.8 \times 9.0$ & 25.2 & $1 / 167$ & 48 & 0.053 & 7.638 & 12.42 \\
\hline 19 & 12 & 3 & 4 & $2.1 \times 12.0$ & 25.2 & $1 / 167$ & 48 & 0.044 & 6.355 & 11.33 \\
\hline 20 & 12 & 2 & 6 & $1.4 \times 18.0$ & 25.2 & $1 / 167$ & 48 & 0.035 & 5.047 & 10.10 \\
\hline 21 & 12 & 1 & 12 & $0.7 \times 36.0$ & 25.2 & $1 / 167$ & 48 & 0.013 & 1.837 & 6.09 \\
\hline 22 & 16 & 4 & 4 & $2.8 \times 12.0$ & 33.6 & $1 / 125$ & 36 & 0.041 & 10.360 & 10.85 \\
\hline 23 & 16 & 2 & 8 & $1.4 \times 24.0$ & 33.6 & $1 / 125$ & 36 & 0.019 & 4.836 & 7.41 \\
\hline 24 & 16 & 1 & 16 & $0.7 \times 48.0$ & 33.6 & $1 / 125$ & 36 & 0.012 & 2.957 & 5.80 \\
\hline 25 & 18 & 3 & 6 & $2.1 \times 18.0$ & 37.8 & $1 / 111$ & 32 & 0.050 & 16.287 & 12.09 \\
\hline 26 & 18 & 6 & 3 & $4.2 \times 9.0$ & 33.8 & $1 / 111$ & 32 & 0.033 & 10.570 & 9.74 \\
\hline 27 & 24 & 6 & 4 & $4.2 \times 12.0$ & 50.4 & $1 / 83$ & 24 & 0.041 & 23.648 & 10.93 \\
\hline 28 & 24 & 4 & 6 & $2.8 \times 18.0$ & 50.4 & $1 / 83$ & 24 & 0.031 & 17.866 & 9.50 \\
\hline 29 & 24 & 3 & 8 & $2.1 \times 24.0$ & 50.4 & $1 / 83$ & 24 & 0.017 & 9.795 & 7.03 \\
\hline 30 & 24 & 2 & 12 & $1.4 \times 36.0$ & 50.4 & $1 / 83$ & 24 & 0.007 & 4.218 & 4.62 \\
\hline 31 & 24 & 1 & 24 & $0.7 \times 72.0$ & 50.4 & $1 / 83$ & 24 & 0.008 & 4.506 & 4.77 \\
\hline 32 & 32 & 4 & 8 & $2.8 \times 24.0$ & 67.2 & $1 / 63$ & 18 & 0.015 & 15.569 & 6.65 \\
\hline 33 & 32 & 2 & 16 & $1.4 \times 48.0$ & 67.2 & $1 / 63$ & 18 & 0.008 & 8.144 & 4.81 \\
\hline 34 & 36 & 6 & 6 & $4.2 \times 18.0$ & 75.6 & $1 / 55$ & 16 & 0.031 & 39.487 & 9.42 \\
\hline 35 & 36 & 3 & 12 & $2.1 \times 36.0$ & 75.6 & $1 / 55$ & 16 & 0.007 & 9.645 & 4.65 \\
\hline 36 & 48 & 6 & 8 & $4.2 \times 24.0$ & 100.8 & $1 / 42$ & 12 & 0.016 & 35.818 & 6.73 \\
\hline 37 & 48 & 4 & 12 & $2.8 \times 36.0$ & 100.8 & $1 / 42$ & 12 & 0.005 & 12.220 & 3.93 \\
\hline 38 & 48 & 3 & 16 & $2.1 \times 48.0$ & 100.8 & $1 / 42$ & 12 & 0.006 & 13.472 & 4.13 \\
\hline 39 & 48 & 2 & 24 & $1.4 \times 72.0$ & 100.8 & $1 / 42$ & 12 & 0.007 & 15.095 & 4.37 \\
\hline 40 & 64 & 4 & 16 & $2.8 \times 48.0$ & 134.4 & $1 / 31$ & 9 & 0.005 & 20.982 & 3.86 \\
\hline 41 & 72 & 6 & 12 & $4.2 \times 36.0$ & 151.2 & $1 / 28$ & 8 & 0.005 & 28.138 & 3.97 \\
\hline 42 & 72 & 3 & 24 & $2.1 \times 72.0$ & 151.2 & $1 / 28$ & 8 & 0.006 & 29.975 & 4.10 \\
\hline 43 & 96 & 6 & 16 & $4.2 \times 48.0$ & 201.6 & $1 / 21$ & 6 & 0.006 & 51.872 & 4.05 \\
\hline 44 & 96 & 4 & 24 & $2.8 \times 72.0$ & 201.6 & $1 / 21$ & 6 & 0.005 & 46.519 & 3.83 \\
\hline 45 & 144 & 6 & 24 & $4.2 \times 72.0$ & 302.4 & $1 / 14$ & 4 & 0.006 & 122.365 & 4.14 \\
\hline
\end{tabular}

\subsection{Optimum plot size}

Optimum plot size was determined using two statistical procedures as follows:

\subsubsection{Smith's method}

The index of soil variability (b), proposed by
Smith (1938), was estimated from the empirical relationship between plot size and variance per basic unit. This relationship may be expressed in logarithmic form as:

Where:

$$
\log V x=\log v_{i}-b \log x
$$


$\mathrm{V}_{\mathrm{x}}$ : is the variance per basic unit calculated as among plot variance $\mathrm{V}(\mathrm{x})$ divided by the square of plot size in $(\mathrm{x})$ basic units.

$\mathrm{V}_{\mathrm{i}}=$ is the variance among plots of one basic unit. $\mathrm{b}$ : is the regression coefficient which is a measure of the association between adjacent basic units.

Smith (1938) suggested the use of simple weighting of variances by their respective degrees of freedom to calculate (b).

Federer (1955) recommended the following equation to calculate (b):

$$
\mathrm{b}=\frac{\left(\sum w_{i} \log \mathrm{v} x_{i} \log x_{i}\right)-\frac{\left(\sum w_{i} \log v x_{i}\right)\left(\sum w_{i} \log x i\right)}{\left(\sum w_{i}\right)}}{\sum w_{i}\left(\log x_{i}\right)^{2}-\frac{\left(\sum w_{i} \log x i\right)^{2}}{\left(\sum w_{i}\right)}}
$$

Where:

$\mathrm{b}=$ Weighted index of soil variability

$\mathrm{w}_{\mathrm{i}}=$ Degrees of freedom associated with $\mathrm{V}_{\mathrm{Xi}}$

$\mathrm{V}_{\mathrm{Xi}}=$ Weighted variance per basic unit of the ith plot size.

$X_{\mathrm{i}}=$ Number of basic units in the ith plot size

Smith used this index in conjunction with the estimates of cost factors to determine the optimum plot size. However, Hatheway (1961) pointed out that in field research, scientists are generally more interested in designing experiments that are able to detect difference of specified size ignoring cost factors. Therefore, the optimum plot size was calculated from the formula

$\mathrm{X}_{\text {Opt. }}=\mathrm{b} /(1-\mathrm{b})$

\subsubsection{Maximum curvature procedure}

The second method used was the maximum curvature approach which was modified by Meier and Lessman (1971), and Galal and Abou ElFittouh (1971).

The point of maximum curvature $\left(\mathrm{X}_{0}\right)$, for the exponential curve $\left(\mathrm{C} . \mathrm{V} .=\mathrm{Ax}^{-\mathrm{B}}\right)$ relating the coefficient of variability (C.V.) and plot size (x), was determined using the following equation:

$\mathrm{X}_{0}=\left(\mathrm{A}^{2} \mathrm{~B}^{2}(2 \mathrm{~B}+1) /(\mathrm{B}+2)\right)^{1 /(2 \mathrm{~B}+2)}$

Using the principles of linear regression, values of $\mathrm{A}$ and $\mathrm{B}$ were estimated as follows:

$$
\begin{gathered}
\mathrm{B}=\frac{\mathrm{n} \sum \log (\mathrm{c}, \mathrm{v}) \log \mathrm{x}-\sum \log (\mathrm{c}, \mathrm{v}) \sum \log \mathrm{x}}{\mathrm{n} \sum(\log \mathrm{x})^{2}-\left(\sum \log \mathrm{x}\right)^{2}-} \\
\log \mathrm{A}=\frac{\sum \log (\mathrm{c}, \mathrm{v})}{\mathrm{n}}-\mathrm{B} \frac{\sum \log \mathrm{x}}{\mathrm{n}}
\end{gathered}
$$

The equation used to determine $\mathrm{X}_{0}$ was then converted to logarithmic form as follows:

$$
\log \mathrm{x}_{0}=\frac{2 \log \mathrm{n}+2 \log \mathrm{B}+\log (2 B+1)-\log (\mathrm{B}+2)}{(2 \mathrm{~B}+2)}
$$

Plot size directly beyond the $\mathrm{X}_{0}$ value on the curve is considered optimum.

\subsubsection{Optimum plot shape}

To study the effect of plot shape, differences among shapes, of plots composed of the same number of basic units, were tested for significance by comparing their variances using Bartlett Chi square test for homogeneity of variances as outlined by Steel and Torrie (1980).

\subsubsection{Optimum number of replications}

Several methods can be used to determine the required number of replications, based on the coefficient of variation to detect a specified percentage difference between treatment means. A commonly used method, based on Student " $t$ " statistic, was given by Federer (1955). The number of replications of different plot sizes for the two trials was calculated according to the following formula:

$$
r=\frac{2 t^{2} \propto(C . V \cdot)^{2}}{D^{2}}
$$

Where:

$t$ : is the value of Students" $t$ " the level of significance for degrees of freedom associated with the C.V.

$\propto:$ is the significance level

C.V.: is the coefficient of variability

$\mathrm{D}$ : is the minimum difference to be detected, expressed in percentage of the mean.

$r=$ is the appropriate number of replications.

\section{RESULTS AND DISCUSSION}

The Data in Tables (1 and 2) presented the variances per basic unit area, among plots and C.V. for 45 combinations of plot size and shape in the first and second seasons, respectively. Two procedures; namely Smiths method and maximum curvature method were used to estimate the optimum plot size for maize trials grown at Sids region in the 2011 and 2012 seasons.

\subsection{Smith's method}

The following estimates were calculated using the Smith`s method to determine the optimum plot size for each experiment:

\subsubsection{Variance per basic unit area:}

The results in Tables (1 and 2) show that the variance per basic unit area generally decreased with the increase in plot size. The variance per basic unit area in the 2011 season decreased from 0.118 for the smallest plot size (one basic unit) to 0.00002 for the plot size of 144 basic units. On the other hand, in 2012 season variance per basic unit decreased from 0.1930 for one basic unit per plot to 0.0059 for 144 basic units per plot.

\subsubsection{Index of soil variability}

The weighted index of soil variability (b) proposed by Federer (1955) was found to be 
0.8984 in the first season and 0.7422 for the second season as shown in Table (3). The coefficient of soil heterogeneity (B) is a reflection of the association between adjacent plots and it is expected to vary between zeros to one. The value near zero denotes complete uniformity and the value near one denotes random soil variability. Thus, the obtained values of soil variability index in both seasons reflect moderate variability in the soil of the experiment at Sids region.

Table (3): Optimum plot size estimated using Smith's method in 2011 and 2012 seasons.

\begin{tabular}{|c|c|c|c|c|}
\hline \multirow{2}{*}{ Seasons } & \multirow{2}{*}{ B } & \multicolumn{3}{|c|}{ Optimum plot size } \\
\cline { 3 - 5 } & & Basic & \multicolumn{2}{|c|}{ Plot area } \\
\cline { 3 - 5 } & & $\mathbf{m}^{\mathbf{2}}$ & Feddan \\
\hline 2011 & 0.8984 & 9 & 18.9 & $1 / 222$ \\
\hline 2012 & 0.7422 & 3 & 6.3 & $1 / 667$ \\
\hline
\end{tabular}

\subsubsection{Optimum plot size}

Values of soil variability index (B) were used to calculate the optimum plot size which was found to be 9 and 3 basic units in the first and the second seasons, respectively. Consequently it may be concluded that the optimum plot size was 9 basic units or $18.9 \mathrm{~m}^{2}$ (1/222 feddan) in the first season and 3 basic units or $6.3 \mathrm{~m}^{2}$ (1/667 feddan) for the second season.

\subsection{Maximum curvature method}

Average variance per basic unit, average yield and average of observed and estimated coefficient of variability for each plot size are presented in Table (4). The results showed that the value of the coefficient of variation generally decreased as plot size increased. Coefficient of variation decreased from 34.20 for one basic unit per plot to 1.64 for a plot size of 144 basic units in the first season and correspondingly from 26.50 for one basic unit per plot to 3.28 for 144 basic units per plot in the second season. On the other hand, the reduction in c.v was not in proportion with the increase in the plot size. Moreover, the rate of reduction decreased as plot size became larger. This confirms the fact that the relationship between plot size and the variance per basic unit or the coefficient of variability is of exponential nature.

The exponential relationships obtained for the current study were found to be C.V $=34.20 \mathrm{X}$ 0.6167 and C.V. $=26.5 \mathrm{X}^{-0.4216}$ for the first and the second seasons, respectively, where (X) is the plot size. These relations were graphically illustrated in Figs.(1 and 2) for the first and the second seasons, respectively.

Table (4): Average variance per basic unit $\left(v_{x}\right)$, average yield (Y) and average coefficient of variability (C.V.) for each plot size in 2011 and 2012 seasons.

\begin{tabular}{|c|c|c|c|c|c|c|c|c|c|}
\hline \multirow{3}{*}{$\begin{array}{l}\text { Plot } \\
\text { size }\end{array}$} & \multirow{3}{*}{$\begin{array}{c}\text { No. } \\
\text { of } \\
\text { plots }\end{array}$} & \multicolumn{4}{|c|}{2011 season } & \multicolumn{4}{|c|}{2012 season } \\
\hline & & \multirow{2}{*}{$\mathrm{v}_{\mathrm{x}}$} & \multirow{2}{*}{$\mathrm{Y}(\mathrm{kg})$} & \multicolumn{2}{|c|}{ C.V. } & \multirow[b]{2}{*}{$\mathrm{v}_{\mathrm{x}}$} & \multirow{2}{*}{$Y(k g)$} & \multicolumn{2}{|c|}{ C.V. } \\
\hline & & & & Observed & Estimated & & & Observed & Estimated \\
\hline 1 & 576 & 0.1180 & 1.50 & 22.90 & 34.20 & 0.1930 & 1.85 & 23.70 & 26.50 \\
\hline 2 & 288 & 0.0710 & 3.00 & 17.78 & 22.40 & 0.1160 & 3.71 & 18.37 & 19.78 \\
\hline 3 & 192 & 0.0468 & 4.49 & 14.27 & 17.48 & 0.0912 & 5.56 & 16.28 & 16.68 \\
\hline 4 & 144 & 0.0402 & 5.99 & 13.23 & 14.67 & 0.0756 & 7.42 & 14.82 & 14.77 \\
\hline 6 & 96 & 0.0273 & 8.99 & 10.75 & 11.45 & 0.0620 & 11.12 & 13.39 & 12.45 \\
\hline 8 & 72 & 0.0273 & 11.99 & 10.87 & 9.61 & 0.0454 & 14.83 & 11.37 & 11.03 \\
\hline 9 & 64 & 0.0119 & 13.48 & 7.28 & 8.94 & 0.0572 & 16.68 & 12.91 & 10.49 \\
\hline 12 & 48 & 0.0135 & 17.98 & 8.36 & 7.50 & 0.0398 & 22.25 & 10.49 & 9.29 \\
\hline 16 & 36 & 0.0216 & 23.97 & 9.60 & 6.29 & 0.0237 & 29.66 & 8.02 & 8.23 \\
\hline 18 & 32 & 0.0053 & 26.97 & 4.86 & 5.85 & 0.0415 & 33.37 & 10.92 & 7.83 \\
\hline 24 & 24 & 0.0133 & 35.96 & 7.08 & 4.91 & 0.0208 & 44.49 & 7.37 & 6.94 \\
\hline 32 & 18 & 0.0145 & 47.94 & 7.79 & 4.12 & 0.0116 & 59.32 & 5.73 & 6.15 \\
\hline 36 & 16 & 0.0038 & 53.94 & 3.00 & 3.83 & 0.0190 & 66.74 & 7.03 & 5.85 \\
\hline 48 & 12 & 0.0078 & 71.91 & 4.98 & 3.22 & 0.0083 & 88.98 & 4.79 & 5.18 \\
\hline 64 & 9 & 0.0063 & 45.89 & 5.29 & 2.70 & 0.0051 & 118.64 & 3.86 & 4.59 \\
\hline 72 & 8 & 0.0011 & 107.87 & 2.07 & 2.51 & 0.0056 & 133.47 & 4.04 & 4.37 \\
\hline 96 & 6 & 0.0032 & 143.83 & 2.82 & 2.11 & 0.0053 & 177.97 & 3.94 & 3.87 \\
\hline 144 & 4 & 0.0001 & 215.74 & 0.33 & 1.64 & 0.0059 & 266.95 & 4.14 & 3.28 \\
\hline
\end{tabular}




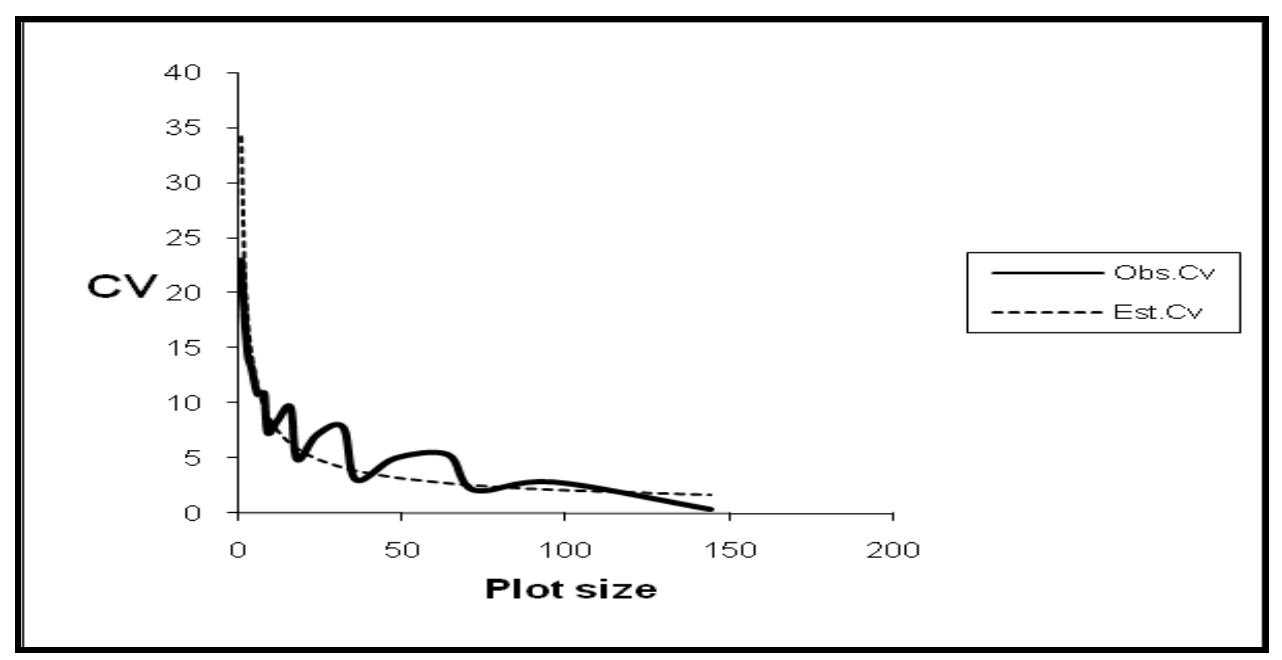

Fig. (1): Relationship between plot size and coefficient of variation (CV) in 2011 season.

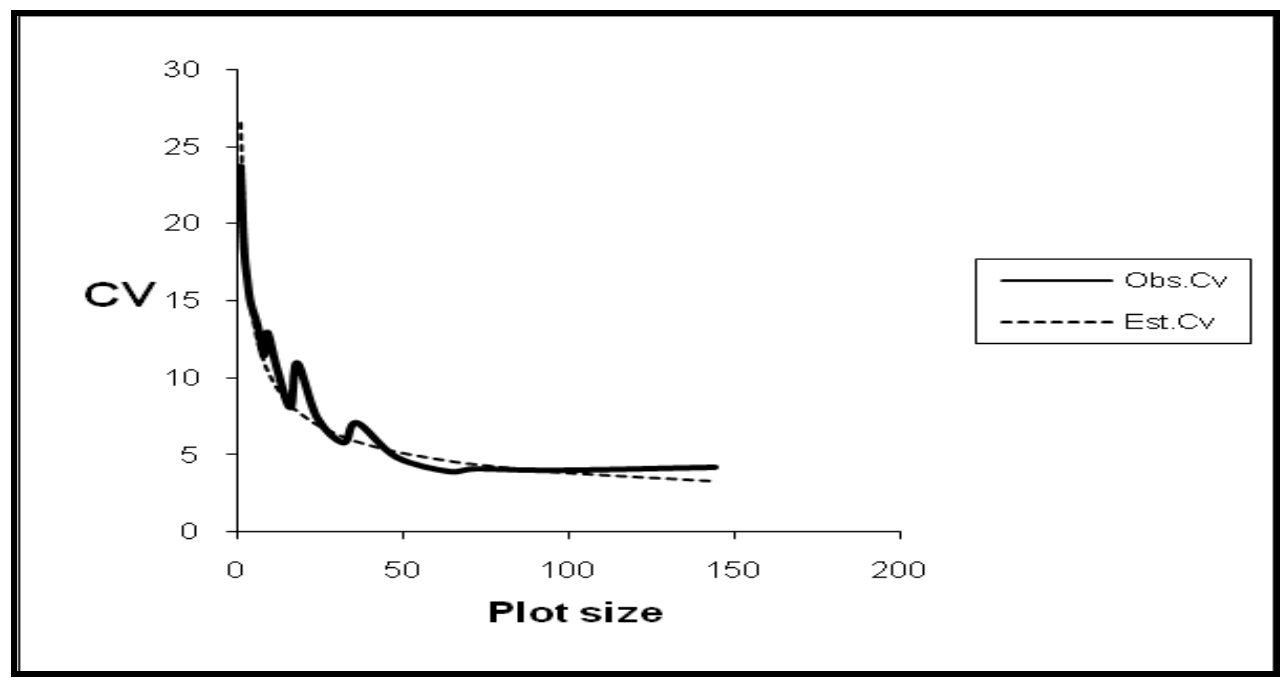

Fig. (2): Relationship between plot size and coefficient of variation (CV) in 2012 season

According to the maximum curvature method, the coefficient of variation is used as an indicator of optimum plot size and it is graphed on the $(\mathrm{Y})$ axis in relation to various plot sizes on $(\mathrm{x})$ axis (Figs. 1 and 2). On the other hand, the optimum plot size is considered to be the point on the curve where the rate of change in the estimate of $(Y)$ per increase of $(\mathrm{x})$ is greatest, thus called the maximum curvature. The point of maximum curvature was 6.27 and 8.81 in the first and the second seasons, respectively. The optimum plot size was 7 basic units for the first season, being $14.7 \mathrm{~m}^{2}$ or $1 / 286$ feddan and 9 basic units in the second season, being $18.9 \mathrm{~m}^{2}$ or $1 / 222$ feddan (Table 5).

Generally, the estimated optimum plot size is always affected by several factors that might cause extreme fluctuations such as crop, location, agricultural practices, size of performed basic unit and statistical technique utilized for calculating such optimum size plot.

Several investigators have obtained similar results for the optimum plot size in various crops, including, Fleming et al. (1957) (3.5 feet wide by

Table (5): Optimum plot size estimated using the maximum curvature method in 2011 and 2012 seasons.

\begin{tabular}{|c|c|c|c|c|c|}
\hline \multirow{2}{*}{ Seasons } & \multirow{2}{*}{ A } & \multirow{2}{*}{ B } & \multicolumn{3}{|c|}{ Optimum Plot size } \\
\cline { 4 - 6 } & & & Basic & \multicolumn{2}{|c|}{ Plot area } \\
\cline { 4 - 6 } & & & unit & $\mathbf{m}^{\mathbf{2}}$ & Feddan \\
\hline 2011 & 34.20 & -0.6167 & 7 & 14.7 & $1 / 286$ \\
\hline 2012 & 26.50 & -0.4216 & 9 & 18.9 & $1 / 222$ \\
\hline
\end{tabular}

8.75 feet long for hybrid corn), Galal and Abou El- Fittouh (1971) (18 to $29 \mathrm{~m}^{2}$ in cotton), Poultney and Webster (1997) $\left(1 \mathrm{~m}^{2}\right.$ to $16 \mathrm{~m}^{2}$ in terraces), Ashmawy (2004) (1/667 to $1 / 400 \mathrm{fed}$ in 
maize), Mohamed (2005) (8.6 $\mathrm{m}^{2}$ to $11.5 \mathrm{~m}^{2}$ using Smith's procedure, $27.1 \mathrm{~m}^{2}$ to $38.9 \mathrm{~m}^{2}$ by maximum curvature, in maize), and Kavitha (2010) (3.6 $\mathrm{m}^{2}$ in soybean).

\subsection{Plot shape}

The results of Bartlett test for the homogeneity of variances for different plot shapes of a given plot size in 2011 and 2012 seasons are shown in Table (6). The results clearly reported that the variances of different shapes for the respective given plot size significantly varied for all cases

Table (6):Results of the Bartlett's test for the homogeneity of variences for different plot shapes of maize trials in 2011 and 2012 seasons

\begin{tabular}{|c|c|c|}
\hline \multirow{2}{*}{$\begin{array}{l}\text { No. of basic } \\
\text { units per plot }\end{array}$} & \multicolumn{2}{|c|}{ Chi - square value } \\
\cline { 2 - 3 } & $\mathbf{2 0 1 1}$ & $\mathbf{2 0 1 2}$ \\
\hline 2 & 1.51 & 0.38 \\
\hline 3 & $16.97 * *$ & 0.37 \\
\hline 4 & $18.61 * *$ & 1.69 \\
\hline 6 & $37.50^{* *}$ & 4.41 \\
\hline 8 & $12.71 * *$ & $9.27 *$ \\
\hline 12 & $40.54 * *$ & $23.43 * *$ \\
\hline 16 & $9.63 * *$ & $13.35^{* *}$ \\
\hline 18 & 0.54 & 1.42 \\
\hline 24 & $32.28 * *$ & $20.86 * *$ \\
\hline 32 & $4.24 *$ & 1.67 \\
\hline 36 & 1.08 & $6.74 * *$ \\
\hline 48 & $23.98^{* *}$ & 3.38 \\
\hline 72 & $4.92^{*}$ & 0.01 \\
\hline$*$ and **: Significant and highly significant at 0.05 \\
and 0.01 probability levels, respectively. \\
\hline
\end{tabular}

except for the plot sizes of 2,18 and 36 basic units in the first season. In the second season, changing the plot shape for a specified plot size, significantly affected only the variances of plot sizes of $8,12,16,24$ and 36 basic units.

Referring to Tables (1 and 2) and comparing the variances of different shapes for a given plot size, it may be concluded that long and narrow plots for a specified plot size were generally more efficient (low estimates of variance per basic unit and coefficient of variability) as compared with other shapes in the first season.

In 2012 season, the variance per basic unit and the coefficient of variability, for a fixed plot size, decreased as plot size increased more along the strips than through number of rows indicating that the short and wide plots were more statistically valid. Accordingly, the soil heterogeneity is ranked first as the limiting factors in identifying the optimum plot size and shape. These results are in accordance with the findings obtained by ElRassas et al. (1982), El-Rayes et al (1993) and ElTaweel (1999).

The investigator must take into account some important practical rules when determining the most desirable plot size and shape in the field experiments. The field plot should be sufficiently large to include a representative sample of the crop population, allow the elimination of border effects and to apply the experimental materials and their respective agricultural practices. On the contrary, the plot size should be sufficient by small to minimize the soil heterogeneity (intra plot variability) (Galal and Abou El-Fittouh, 1971).

\subsection{Number of replications:}

Table (7) shows the number of replications required to detect differences of $15 \%$ and $20 \%$

Table (7): Number of replications required to detect differences of $15 \%$ and $20 \%$ among treatment means at the $5 \%$ level of significance for maize trials in 2011 and

\begin{tabular}{|c|c|c|c|c|c|}
\hline \multicolumn{2}{|c|}{ Plot size } & \multirow{2}{*}{\multicolumn{2}{|c|}{$\begin{array}{l}\text { Required number of } \\
\text { replications in } 2011 \text { season }\end{array}$}} & \multirow{2}{*}{\multicolumn{2}{|c|}{$\begin{array}{l}\text { Required number of } \\
\text { replications in } 2012 \text { season }\end{array}$}} \\
\hline \multirow{2}{*}{$\begin{array}{l}\text { Number of } \\
\text { basic units }\end{array}$} & \multirow{2}{*}{$\begin{array}{l}\text { Plot area } \\
\left(\mathbf{m}^{2}\right)\end{array}$} & & & & \\
\hline & & $\begin{array}{c}15 \% \\
\text { differences }\end{array}$ & $\begin{array}{c}20 \% \\
\text { differences }\end{array}$ & $\begin{array}{c}15 \% \\
\text { differences }\end{array}$ & $\begin{array}{c}20 \% \\
\text { differences }\end{array}$ \\
\hline 1 & 2.1 & 40 & 22 & 24 & 13 \\
\hline 2 & 4.2 & 17 & 10 & 13 & 8 \\
\hline 3 & 6.3 & 11 & 6 & 10 & 5 \\
\hline 4 & 8.4 & 7 & 4 & 8 & 4 \\
\hline 6 & 12.6 & 5 & 3 & 5 & 3 \\
\hline 8 & 16.8 & 3 & 2 & 4 & 2 \\
\hline 9 & 18.9 & 3 & 2 & 4 & 2 \\
\hline 12 & 25.2 & 2 & 1 & 3 & 2 \\
\hline 16 & 33.6 & 2 & 1 & 3 & 2 \\
\hline 18 & 37.8 & 1 & 1 & 2 & 1 \\
\hline 24 & 50.4 & 1 & 1 & 2 & 1 \\
\hline
\end{tabular}


between treatment means. In the first season, the number of replications required to detect a $15 \%$ difference between treatments means decreased from 40 replicates for a plot size of one basic unit, to one replicate for plots comprising 24 basic units. For detecting a $20 \%$ difference, the number of replicates varied from 22 for a plot size of one basic unit, to one replicate for a plot size of 24 basic units.

In the second season, the number of replications required to detect a $15 \%$ difference decreased from 24 replicates for the plot size of one basic unit to 2 replications for the plot size of 24 basic units. To detect a $20 \%$ difference, the number of replicates decreased from 13 with for the plot size of one basic unit to one replicate for plots comprising 24 basic units.

Thus, number of replications required for detecting differences of $15 \%$ and $20 \%$ among treatment means generally decreased with the increase in plot size, but the reduction was not in proportion with the increase in plot size. The results show that the highest number of replications was required for the plot size of one basic unit.

In this investigation, the optimum size was 3 to 9 basic units. Consequently, the required number of replications for detecting a $15 \%$ difference between treatment means would be 3 to 11 replications in the first season and 4 to 10 in the second season. For detecting a $20 \%$ difference among treatment means, it was found that 2 to 6 replications in the first season and 2 to 5 replications in the second season would be necessary. The present results are in harmony with those obtained by El-Taweel (1999) and Mohamed (2005).

\section{REFERENCES}

Ashmawy F. (2004).Increasing precision of field experiments in maize using uniformity trials. J. Agric. Sci., Mansoura Univ., 29 (3):10651076.

El-Kalla S. E. and Gomaa A. A. ( 1977). Estimation of soil variability and optimum plot size and shape for wheat (Triticum aestivum L.) trials. Agric. Res. Rev., 9:81-88.

El-Rassas H. N. (1982). Precision of some statistical procedures in evaluating yield components of some cereal crops. Ph.D.Thesis, Fac. Agric., Cairo Univ., Egypt.

El-Rayes F. M., Thanaa. M. El-Gammal Mohamed T.A. and Hannan, L.T. (1993). Optimum plot size shape and number of replications for wheat yield trials in middle Egypt. Agric.Res. Rev., 71:1-16.
El-Taweel A. M. A. (1999). Field plot technique studies in maize experiments. Ph.D. Thesis, Fac. Agric., Al-Azhar Univ., Egypt.

Federer W. T. (1955). Experimental Designs. McMillan Co., New York U.S.A.

Fleming A. A., Rogers T. H. and Bancroft T. A. ( 1957). Field plot technique with hybrid corn under Alabama conditions. Agron. J., 49:1-4.

Galal H. E. and Abou El-Fittouh H.A.A. (1971). Estimation of optimum plot size and shape for Egyptian cotton yield trials. Alex. J. Agric. Res., 19:233- 238.

Gomez K.A. and Gomez A.A. (1984). Statistical Procedures for Agricultural Research. $2^{\text {nd }}$ ed., John Wiley \& Sons New York, USA.

Hatheway W. H. (1961). Convenient plot size. Agron. J., 63:273-38.

Joshi S. N., Kabaria M. M. and Baraia L .H. (1973). Note on the estimates of optimum plot size for field experiments on soybean. Indian J. Agric. Sci., 43:423- 424.

Kassem A. A., Khadr F. H. and El-Rouby M. M. (1972). Optimum size and shape of plots and relative efficiency of different designs of yield trials in wheat. Alex. J. Agric. Res., 19: 223 232.

Kavitha B. (2010). Study on optimum plot size and optimum plot shape of soybean crop. M.sc. Sci. Thesis, Fac. Agric., Dharwad Univ.

Khalil A. R., Kasdy A. M., Abou-El-Fittouh H. A. El-Gamal T. M. and El- Rayes F. M. ( 1973). Opimum plot size and shape in field trials. II. Paddy and broad bean. Agric. Res. Rev., 51:115- 122.

Khalil A. R., El-Kalla S. E. and Kasdy A. M. ( 1971). Optimum plot size and shape in field trials. Cotton. Agric. Res. Rev., 49:13- 24.

Leilah A. A. and Al-Barrak K. M. ( 2005). Estimation of optimum field size and shape and number of replications in sorghum yield trials. J. King Saoud Univ., Agric. Sci., (2): $101-166$.

Masood M. A. and Raza I.(2012). Estimation of optimum field plot size and shape in paddy yield trials. American-Eurasian J. Sci. Res.7 (6): 264-269.

Meier V.D. and Lessman K.J. (1971).Estimation of optimum field plot shape and size for testing yield in Crambe abyssinica Hochst. Crop Sci., 11:648 - 650 .

Mohamed N. A. (2005). Influence of plot size and number of replications on precision of field experiments with maize grown under different fertilization conditions and plant densities. J. Agric. Sci., Mansoura Univ., 30(2):763-772. 
Poultney R. R. and Webster J. R. (1997). Optimizing plot size and shape for field experiments on terraces. Exp. Agric., 33 (1):51-64.

Smith H. F. (1938). An empirical law describing heterogeneity in yields of agricultural crops. J. Agric. Sci., 28:1-23.

Steel R. G. D. and Torrie J. H. (1980). Principles and Procedures of Statistics. Mc- Graw Hill Book Co., Inc., New York, USA.

\section{إستخدام تجارب التجانس لتقدير أنسب مساحة وشكل للقطعة التجريبية وعدد المكررات فى تجارب محصول الذبرة الثامية}

شابون عبد العزيز منصور شابون - هيام سيد احمد فاتح* - وليد محمد فارس*

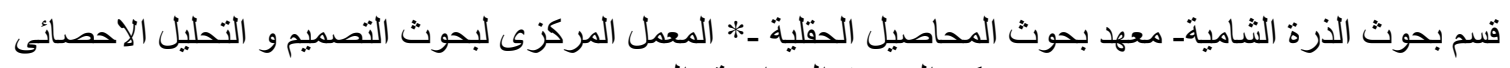

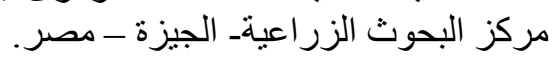

\section{ملخص}

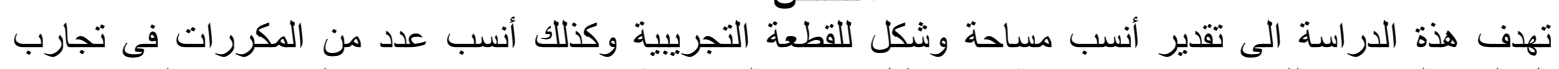

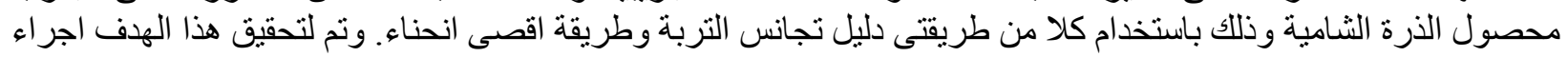

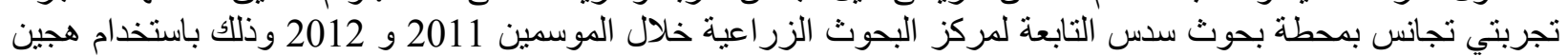

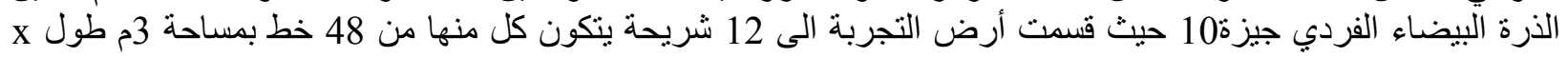

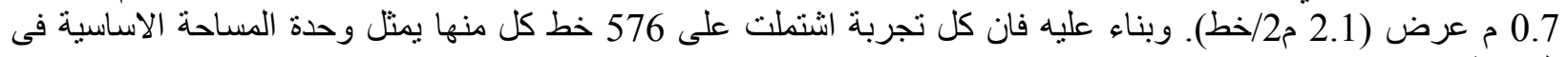

أظظهرت النتائج ان زيادة مساحة القطعة التجريبية أدت الى نقص كل من التباين لوحدة المساحة ومعامل الاختلاف , ولكن التجربة.

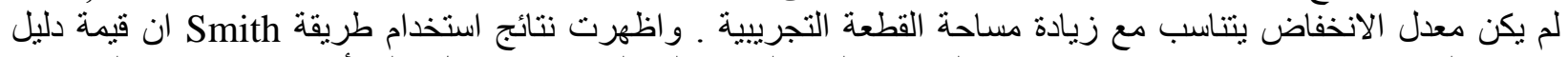

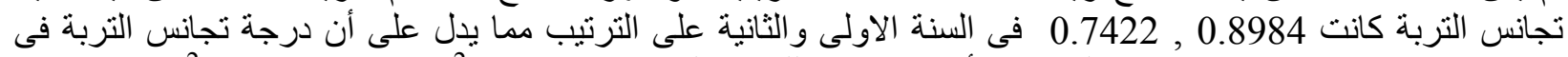

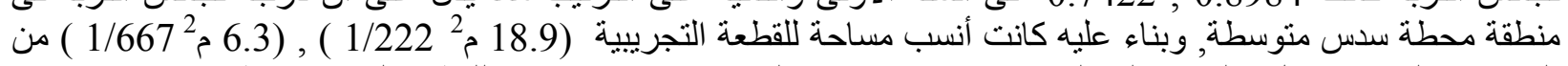

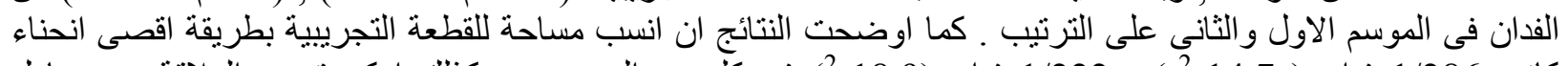

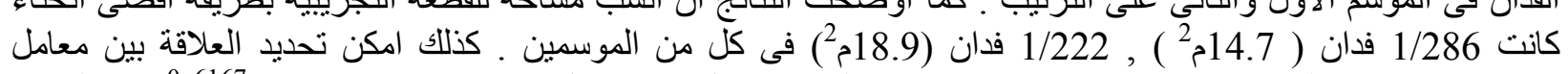

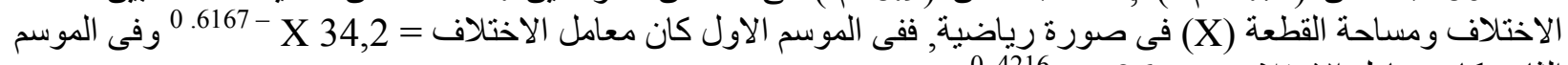

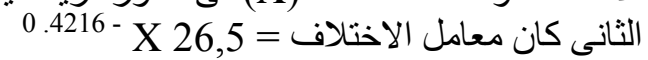

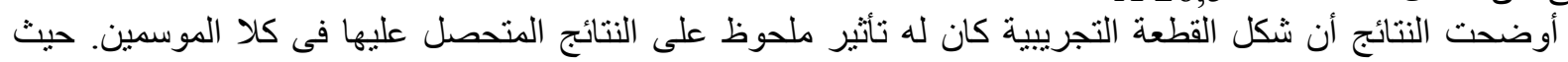

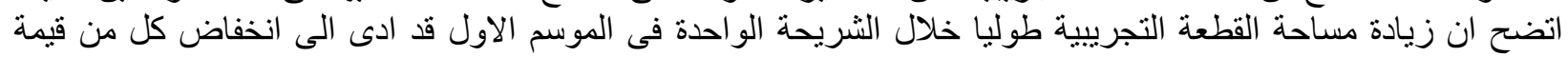

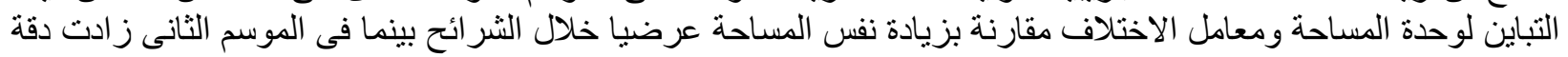

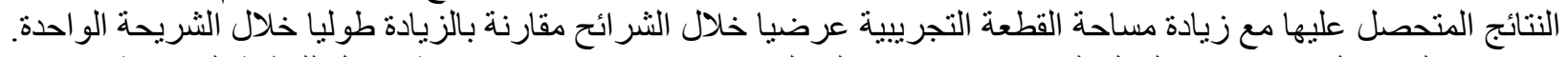

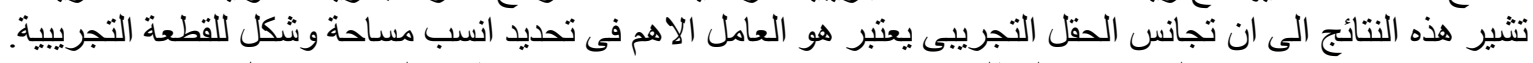

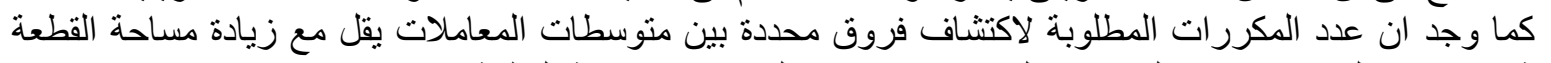

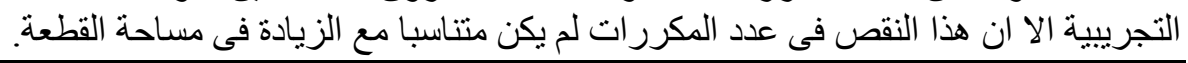

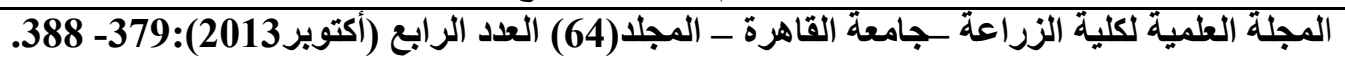

